\title{
Thermal structure of the deep Lopra-1/1 A borehole in the Faroe Islands
}

\author{
Niels Balling, Niels Breiner and Regin Waagstein
}

Information on temperature, temperature gradients, thermal conductivity and heat flow from the $c$. $3.5 \mathrm{~km}$ deep Lopra-1/1A borehole in the Faroe Islands is presented and analysed. The upper $2450 \mathrm{~m}$ of the drilled sequence consists of thick tholeiitic basalt flows and the deeper parts of hyaloclastites and thin beds of basalt. Temperature data originate from high precision temperature logging a long time after drilling to a depth of $2175 \mathrm{~m}$ (the original Lopra-1 borehole) and from commercial temperature logs measured a short time after drilling to a depth of $3430 \mathrm{~m}$ (Lopra-1/1A). The high-precision temperature log determines accurately levels of inflow of groundwater to the borehole and significant thermal disturbances to a depth of $c .1250 \mathrm{~m}$. Below $1300 \mathrm{~m}$, no significant disturbances are seen and interval temperature gradients for large depth intervals show only small variations between 28 and $33^{\circ} \mathrm{C} / \mathrm{km}$. The mean least-squares gradient for the depth interval of $1400-3430 \mathrm{~m}$ is $31.4^{\circ} \mathrm{C} /$ $\mathrm{km}$. In clear contrast to these overall very homogeneous, large-interval, mean temperature gradients, great local variability, between gradients of $20-25^{\circ} \mathrm{C} / \mathrm{km}$ and $45^{\circ} \mathrm{C} / \mathrm{km}$, was observed between about 1300 and $2175 \mathrm{~m}$ (maximum depth of the high-resolution temperature log). These gradient variations are interpreted to be due to thermal conductivity variations and to reflect varying secondary mineralisation and mineral alterations.

A preliminary analysis of the Lopra-1/1A temperature-depth function in terms of long-term palaeoclimatic signals indicates subsurface temperatures below about $1300 \mathrm{~m}$ to be in equilibrium with mean surface temperatures significantly below zero during the last glacial period. A subsequent temperature increase of $12-16^{\circ} \mathrm{C}$ occurred at around the termination of the last glaciation. The measured temperatures (some after correction) and the thermal regime below $1300 \mathrm{~m}$ seem to represent conductive equilibrium conditions without significant disturbances from the effect of drilling, groundwater flow or long-term palaeoclimatic surface temperature variations.

Thermal conductivity measured on samples of basalt taken from drill cores and surface outcrops in the area of the borehole shows values within a rather narrow range and a well-defined mean value for low porosity basalts of about $1.8 \mathrm{~W} / \mathrm{m}^{\circ} \mathrm{C}$, while a few samples of lapilli-tuff/tuff from the borehole gave values around $1.9 \mathrm{~W} / \mathrm{m}^{\circ} \mathrm{C}$. Lapilli-tuff and tuff seem to have higher matrix (grain) conductivity than basalt. Heat flow is estimated at $60 \pm 5 \mathrm{~mW} / \mathrm{m}^{2}$. A heat flow of this magnitude is consistent with the Faroe Islands being underlain by continental crust.

Keywords: Lopra-1/1A borehole, Faroe Islands, temperature gradients, thermal conductivity, heat flow

N.B. \& N.B., Department of Earth Sciences, University of Aarhus, Finlandsgade 8, DK-8200 Aarhus N, Denmark. E-mail: niels.balling@geo.au.dk

R.W., Geological Survey of Denmark and Greenland, Øster Voldgade 10, DK-1350 Copenhagen K, Denmark. 

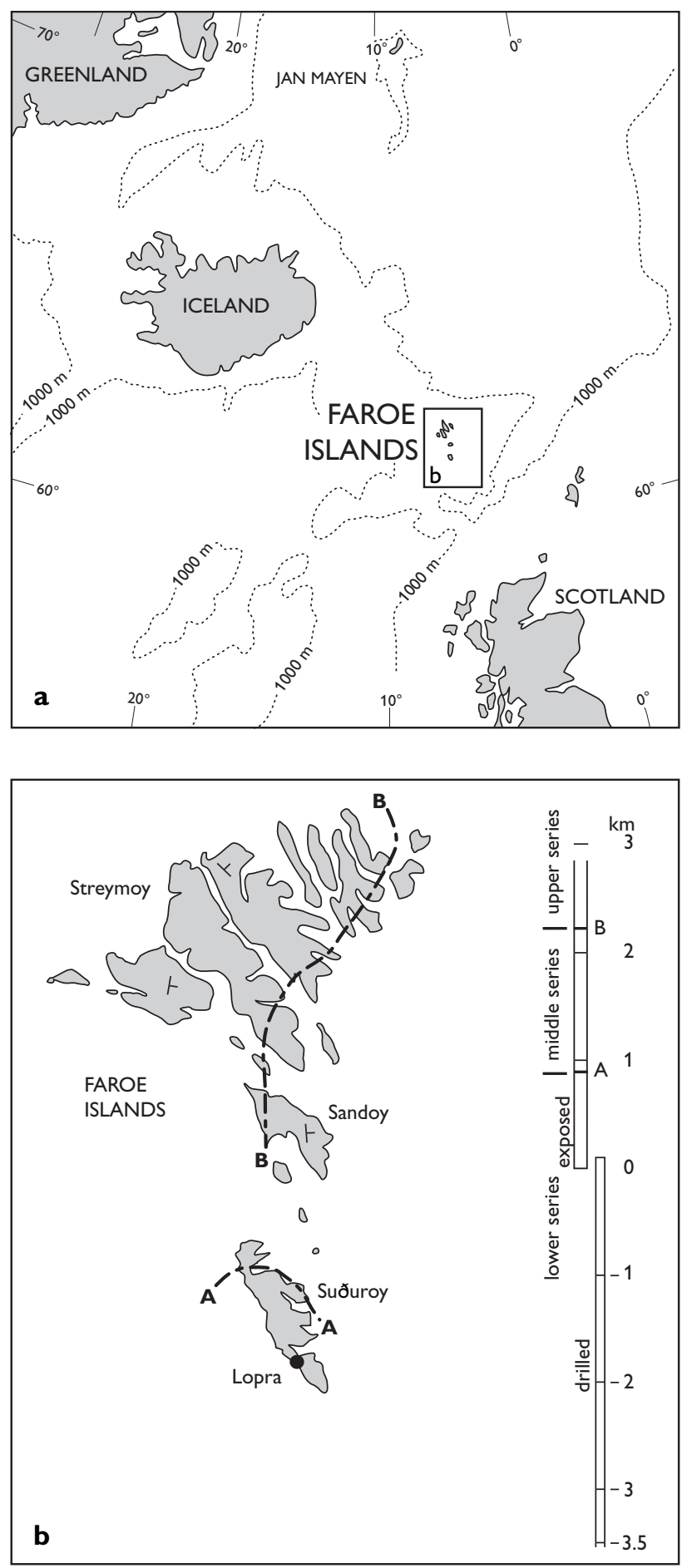

Fig. 1. a: Location map of the Faroe Islands in the northern North Atlantic. b: The Lopra-1/1A borehole was drilled in the southern Faroese island of Suðuroy. The total thickness of volcanic sequences in the Faroe Islands is at least $6.5 \mathrm{~km}$. About $3 \mathrm{~km}$ is exposed, and $3.54 \mathrm{~km}$ was drilled at Lopra-1/1A. Dashed lines A and B mark boundaries between lower and middle and middle and upper basalt series respectively.
Deep boreholes generally provide the most reliable and undisturbed direct information on temperature, temperature gradients, thermal conductivity and heat flow. Temperatures and temperature gradients measured in shallow boreholes may be perturbed for a variety of reasons including local effects of groundwater movements, topography and short- and long-term palaeoclimatic surface temperature variations. The deep Lopra-1/1A borehole provides a unique opportunity for obtaining deep thermal information from an area of the North Atlantic that is of considerable interest to both the general geoscience community and to the hydrocarbon industry.

The Lopra-1/1A borehole is situated in the southern island (Suðuroy) of the Faroe Islands (Fig. 1) (at 61 $26^{\prime}$ $\left.36^{\prime \prime} \mathrm{N}, 6^{\circ} 46^{\prime} 30^{\prime \prime} \mathrm{E}\right)$. It was drilled in 1981 as a research borehole to a depth of $2175 \mathrm{~m}$ below ground level (Berthelsen et al. 1984). In 1996 the borehole was re-entered by a consortium of exploration companies and deepened to $3565 \mathrm{~m}$ measured depth corresponding to a vertical depth below ground level of $3540 \mathrm{~m}$. All depth values given in this paper (if not stated otherwise) are vertical depths measured from ground level $8.8 \mathrm{~m}$ above mean sea level.

Thermal measuring results from the original Lopra-1 borehole were presented by Balling et al. (1984). The purpose of the present paper is to integrate, analyse and discuss all available thermal information from the whole depth range of the Lopra-1/1A borehole. It includes new high-precision continuous temperature logging results from the original hole measured a long time after drilling, temperature measurements from the deepened part acquired as part of the commercial logging runs during and shortly after drilling. New thermal conductivity measurements from core material from the deepened section and from surface exposures in the Lopra-1/1A area have also been made.

Temperatures and temperature gradient variations are analysed in relation to disturbances from groundwater flow, variations in rock thermal conductivity and information on long-term palaeoclimatic surface temperature variations. A new terrestrial heat-flow value for the Lopra-1/1A site is presented.

\section{Geological environment and lithology}

\section{The volcanic succession of the Faroe Islands}

The Faroe Islands form part of the Palaeogene North Atlantic Province of tholeiitic flood basalts. The Faroe volcanic succession has been divided informally into the upper, 
middle and lower basalt series or formations with a total thickness of more than $6.5 \mathrm{~km}$ (Rasmussen \& Noe-Nygaard 1970; Waagstein 1988). The lowermost $3.5 \mathrm{~km}$, which is entirely in the lower basalt formation, is known only from the Lopra-1/1A borehole (Fig. 1).

Both seismic and other geophysical evidence (Bott et al. 1974; Richardson et al. 1998) and geochemical data (Garièpy et al. 1983; Hald \& Waagstein 1983; Holm et al. 2001) indicate that the Faroe Islands are underlain by continental crust. Pre-volcanic rocks have not been reached by drilling. Linear magnetic anomalies associated with oceanic crust occur 60-70 km north of the islands (Skogseid et al. 2000).

The flood basalts were formed by extensive volcanism associated with the continental splitting between NW Europe and East Greenland in upper Paleocene to lowermost Eocene time (e.g. Skogseid et al. 2000). Larsen et al. (1999) used geochemical analyses and stratigraphic correlations between the volcanic successions in the Faroe Islands and East Greenland to interpret the Faroese lower basalt formation as a pre-breakup sequence and the middle and upper basalt formations as syn-breakup sequences. Since deposition of the upper basalt formation, little or no deposition has occurred in the Faroes. Volcanic activity continued, however, on the Greenland side of the rift with the eruption of an additional $3-3.5 \mathrm{~km}$ of basalts in an area then located close to the centre of the Icelandic mantle plume.

\section{Lithology}

The upper $2450 \mathrm{~m}$ of the Lopra-1/1A borehole consists of subaerial lava flows of tholeiitic basalt with an average thickness of about $20 \mathrm{~m}$. Most of the flows have a massive core and a vesicular rubbly top. The lavas are commonly separated by palaeosols made up of volcanic ash or material eroded from the flow tops. The sediments range from a few centimetres to more than $4 \mathrm{~m}$ in thickness. The deeper part of the well, from about $2450 \mathrm{~m}$ to total depth, consists of hyaloclastites (lapilli-tuff and tuff) and thin beds of basalt.

Since deposition, secondary mineralisation and mineral alterations have occurred. The bulk thermal properties of the basaltic sequences seem to be controlled mainly by the two major minerals feldspar and pyroxene, which occur in roughly equal amounts in common basalts. However, it appears from our thermal gradient analysis that within-flow variations of the degree of alteration of the basalt is an important controlling factor for local variations in rock thermal properties and hence temperature gradient variability. Some information on secondary mineral alterations and mineralisation is thus required for a proper thermal analysis.

Olivine is a minor constituent that has been generally replaced by clay. Haematite has formed from iron-rich minerals under oxidising conditions, especially within flow tops and interbasaltic sediments. The original plagioclase feldspar is partly or completely replaced by albite in the deepest part of the borehole due to very low-grade burial metamorphism. Originally variable amounts of interstitial glass representing frozen melt are completely altered to clay and other secondary minerals. Most gas vesicles and pores and fractures once filled with free water are now, particularly at great depth, partly or completely filled with low-temperature minerals deposited by flowing groundwater. These mineralisations consist dominantly of clay and zeolite minerals, silica minerals (chalcedony, agate, quartz) or calcite. The vertical distribution of secondary minerals and zeolite zones of the Lopra-1/1A borehole are described by Jørgensen (1984, 2006, this volume). The lithology and chemistry of the upper $2.2 \mathrm{~km}$ sequence is described in detail by Hald \& Waagstein (1984).

\section{Temperature and temperature gradients}

\section{Temperature logs and conditions of measurements}

Temperature information is available from several temperature logs. Measurements have been carried out by several techniques, either as dedicated temperature logging or in combination with other log operations. Temperatures were measured both during interruptions in the drilling and after the drilling was completed. This applies both to the original Lopra-1 borehole and to the deepened part of Lopra-1/1A.

Temperature logs were run in the original Lopra-1 borehole by The Icelandic Energy Authority, Orkustofnun, the operator of the original hole. The last one was run in 1983, 17 months after drilling. These results are described in detail in Balling et al. (1984). A more detailed continuous temperature log has since been run in the original Lopra-1 hole. It was carried out by the present research group in 1994 to a depth of $2175 \mathrm{~km}$, almost 13 years after drilling, using the high-precision quartz-oscillator system of the University of Aarhus. Measurements were taken while running down-hole at a nominal speed of 10 $\mathrm{cm} / \mathrm{s}$ with a sample rate of two seconds resulting in a sample interval of about $20 \mathrm{~cm}$. Relative temperature resolu- 
Table 1. Basic information about temperature logs from the Lopra-1/1A borehole

\begin{tabular}{lccccc}
\hline $\begin{array}{c}\text { Temp. } \\
\text { log* }\end{array}$ & $\begin{array}{c}\text { Date of } \\
\text { measurement }\end{array}$ & $\begin{array}{c}\text { Depth of } \\
\text { borehole }(\mathrm{m})\end{array}$ & $\begin{array}{c}\text { Depth interval of } \\
\text { temperature data }(\mathrm{m})\end{array}$ & $\begin{array}{c}\text { Time after } \\
\text { drilling/circulation }\end{array}$ & Measuring agency \\
\hline 1 & 23.03 .1983 & 2175 & $0-1974$ & 17 months & Orkustofnun, Reykjavik \\
2 & 04.08 .1994 & 2175 & $0-2175$ & 12 years 9 months & University of Aarhus \\
3 & 01.10 .1996 & 3144 & $3020-3095$ & 5 hours & Schlumberger, Esbjerg \\
4 & 02.10 .1996 & 3144 & $2170-3075$ & 53 hours & Schlumberger, Esbjerg \\
5 & 30.10 .1996 & 3496 & $2990-3430$ & & Schlumberger, Esbjerg
\end{tabular}

* Five logs have been selected to give the most valuable temperature information.

† The time elapsed between the last significant disturbance from drilling or last circulation of drilling fluid and temperature logging.

tion is better than $0.005^{\circ} \mathrm{C}$ and absolute accuracy is calibrated to about $0.05^{\circ} \mathrm{C}$.

All temperature logs from the Lopra-1/1A deepened section below $2175 \mathrm{~m}$ were acquired by the company Schlumberger in combination with other logging opera-

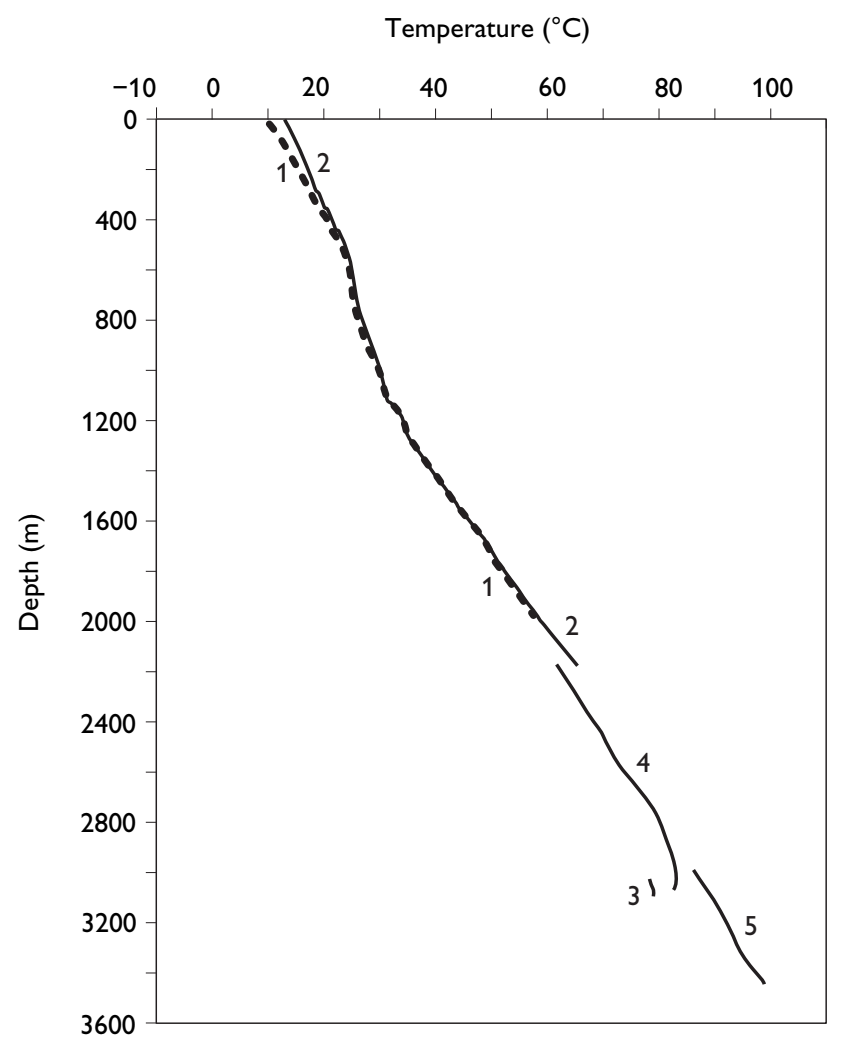

Fig. 2. Selected measured temperature-depth profiles. Logs 1 and 2 are from the original borehole Lopra- 1 and $\operatorname{logs} 3,4$ and 5 were measured in the deepened part. Information on time of measurements, details of depth intervals and time after drilling or last drilling fluid circulation are given in Table 1. Log temperatures presented here are uncorrected. Corrected temperatures are given in Fig. 3. tions relatively soon after drilling activities and circulation of drilling fluid. The temperature data are available as standard six-inch point measurements taken by thermistor probes and are estimated to have an accuracy better than $0.1^{\circ} \mathrm{C}$.

Several temperature logs are thus available both for the original Lopra-1 hole and the deepened Lopra-1/1A section. Five of these have been selected as those giving the most valuable information for interpretation (Table 1 and Fig. 2). They cover depths from the surface to $3430 \mathrm{~m}$.

Drilling and circulation of drilling fluid disturb significantly the temperature structure of the borehole and the unperturbed so-called equilibrium temperature-depth distribution can be measured only a relatively long time after drilling. If sufficient time has not passed, corrections to measurements must be applied (cf. Beck \& Balling 1988).

In general, during circulation of drilling fluid, the upper part of the hole is heated and the lower part is cooled. The time needed for a borehole to reach temperature equilibrium depends on several factors including drilling history, temperature of the drilling mud and the required accuracy of temperature and temperature gradients, but may be relatively long compared to the duration of the drilling. For deep boreholes like the Lopra-1/1A borehole, at least one to two years may be needed to obtain both accurate equilibrium temperatures over the whole section and accurate local temperature gradients. Only for the bottom part of the hole and the neutral zone of least disturbances may near-equilibrium temperatures be measured much sooner after drilling and last drilling fluid circulation.

As mentioned above, temperature measurements were carried out in the original Lopra- 1 borehole to a depth of $2175 \mathrm{~m}$ a long time (up to almost 13 years) after drilling. The temperature logging results from the new section 
drilled in 1996 were, however, carried out no more than 27-53 hours after last drilling fluid circulation, cf. Table 1 , and corrections must be considered.

Temperature disturbances are created not only by the process of drilling. The upper part of the borehole is also affected by upward water flow inside the borehole. After drilling, the Lopra-1 hole (total depth $2175 \mathrm{~m}$ ) started to flow at a rate of about $10 \mathrm{l} / \mathrm{min}$ when the drilling mud was replaced by fresh water of lower density. The well head was closed between the end of drilling and the time of log number 1 (17 months after drilling, cf. Table 1) preventing water from flowing freely to the surface. The hole was opened on the day of temperature logging and after one hour it began to flow at a rate of about $10 \mathrm{l} / \mathrm{min}$. Temperature measurements were carried out from 3 to 6 hours after opening. At the time of $\log$ number 2 , measured in 1994, the hole was flowing freely at about the same rate and had not been closed for several years.

The highest recorded temperature of $98.6^{\circ} \mathrm{C}$ was measured at a depth of $3430 \mathrm{~m}, 53$ hours after circulation when the hole was $3496 \mathrm{~m}$ deep (log 5 from 30 October 1996). The deepest point of temperature information is $3527 \mathrm{~m}$ where $92^{\circ} \mathrm{C}$ was measured on 2 November 1996 , 17 hours after the latest drilling fluid circulation. Two days later, when the drilling had reached its final vertical

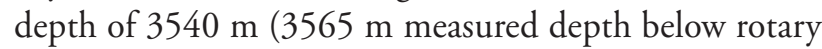
table), a temperature of $91^{\circ} \mathrm{C}$ was measured at $3507 \mathrm{~m}$, 22 hours after circulation of drilling fluid. These lower temperatures measured later at slightly deeper levels demonstrate the effect of cooling by drilling fluid circulation.

\section{Correction of temperatures}

A comparison of the raw temperature data of logs 1 (measured in 1983) and 2 (measured in 1994) shows a difference of $2-3^{\circ} \mathrm{C}$ at depths below $400 \mathrm{~m}$ and an almost constant offset of $2^{\circ} \mathrm{C}$ between 1000 and $1600 \mathrm{~m}$. Such an almost constant difference is very unlikely to be caused by water flow or any other effect associated with the borehole and, from further data analysis, this difference is ascribed to an instrumental calibration offset in $\log 1$ by about $2.0^{\circ} \mathrm{C}$. (Equipment used for $\log 2$ measurements was carefully calibrated before and after logging.) After adding $2.0^{\circ} \mathrm{C}$ to the original $\log 1$ values, $\log 1$ and $\log 2$ measurements agree to within $\pm 0.2^{\circ} \mathrm{C}$ between 1000 and 1600 $\mathrm{m}$, increasing to a maximum difference of $0.7^{\circ} \mathrm{C}$ at 1974 $\mathrm{m}$, the maximum depth of $\log 1$. In the topmost part of the borehole, $\log 2$ shows slightly higher temperature differences (by up to $2-3^{\circ} \mathrm{C}$ ) due to a longer time of temperature disturbance from up-hole water flow (cf. Fig. 2).
Measured $\log 1$ and $\log 2$ temperatures are both clearly elevated in the upper part of the hole because of water flow. At near-surface level, measured temperatures (Fig. 2) are well above the mean ground temperature of about $7^{\circ} \mathrm{C}$. By temperature gradient analysis (se below), levels of water inflow have been localised accurately. Below a depth of about $1250 \mathrm{~m}$, measured temperatures of $\operatorname{logs} 1$ and 2 are unlikely to be disturbed significantly by flow of water in the borehole, and $\log 2$ temperatures are assumed to represent undisturbed equilibrium values.

The temperatures on logs 3, 4 and 5, from depths between 2170 and $3430 \mathrm{~m}$ (Table 1 and Fig. 2), were measured between 27 hours $(\log 3)$ and 53 hours $(\log 5)$ after drilling fluid circulation following drilling activities and are thus disturbed. Measured temperatures on logs 3, 4 and 5 are, due to their deep position in the hole, lowered

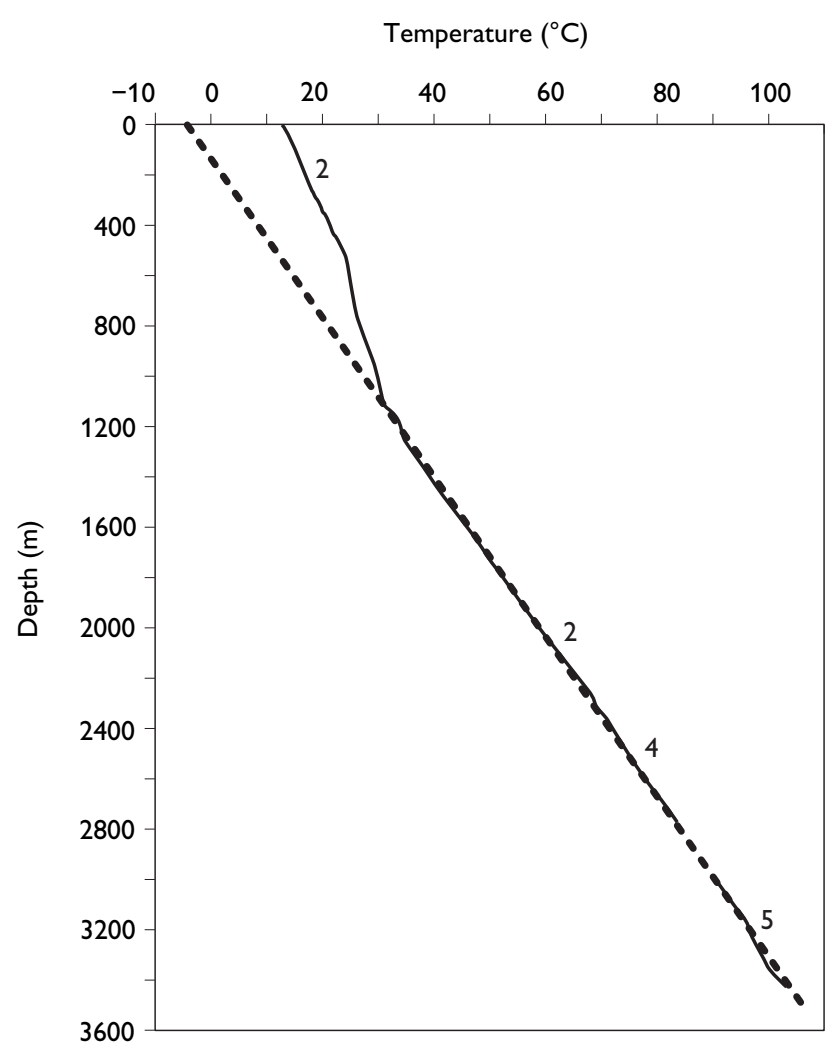

Fig. 3. Measured temperatures on $\log 2$ and corrected temperatures of $\operatorname{logs} 4$ and 5. Corrections were applied for the estimated effect of drilling and drilling fluid circulation. The dashed line has a constant gradient of $31.4^{\circ} \mathrm{C} / \mathrm{km}$ calculated by least-squares for the depth interval of $1400-3450 \mathrm{~m}$ and extrapolated to the surface. The upper part of the borehole (above c. $1200 \mathrm{~m}$ ) is disturbed by upward flow of water inside the borehole. The negative temperature at the surface intercept indicates that temperatures below about $1200-1300 \mathrm{~m}$ are in equilibrium with a palaeosurface-temperature significantly below that of the present-day mean surface temperature of about $7^{\circ} \mathrm{C}$. 
Table 2. Listing of selected temperatures from logs 2, 4 and 5

\begin{tabular}{|c|c|c|c|}
\hline \multirow[b]{2}{*}{ Depth (m) } & \multicolumn{3}{|c|}{ Temperatures $\left({ }^{\circ} \mathrm{C}\right)^{*}$} \\
\hline & $\log 2^{\dagger}$ & $\log 4 \ddagger$ & $\log 5 \ddagger$ \\
\hline 1200 & 34.1 & & \\
\hline 1300 & 36.2 & & \\
\hline 1400 & 39.4 & & \\
\hline 1500 & 42.6 & & \\
\hline 1600 & 46.1 & & \\
\hline 1700 & 49.4 & & \\
\hline 1800 & 52.3 & & \\
\hline 1900 & 55.6 & & \\
\hline 2000 & 58.8 & & \\
\hline 2100 & 62.5 & & \\
\hline 2200 & & 66.2 & \\
\hline 2300 & & 69.1 & \\
\hline 2400 & & 72.0 & \\
\hline 2500 & & 74.7 & \\
\hline 2600 & & 77.8 & \\
\hline 2700 & & 81.5 & \\
\hline 2800 & & n.d. & \\
\hline 2900 & & & n.d. \\
\hline 3000 & & & 90.5 \\
\hline 3100 & & & 93.7 \\
\hline 3200 & & & 96.4 \\
\hline 3300 & & & 98.9 \\
\hline 3400 & & & 102.4 \\
\hline 3430 & & & 103.5 \\
\hline \multicolumn{4}{|c|}{$\begin{array}{l}\text { * Measured temperatures above } 1200 \mathrm{~m} \text { are disturbed by water } \\
\text { flow inside the borehole (cf. Fig. } 3 \text { ) and are not listed. } \\
\text { Temperatures of log } 2 \text { are assumed to represent accurately the } \\
\text { undisturbed equilibrium temperatures. } \\
\ddagger \text { Temperatures of logs } 4 \text { and } 5 \text { are corrected for the estimated } \\
\text { influence of drilling disturbances and may represent equilibrium } \\
\text { temperatures to within } \pm 1-3^{\circ} \mathrm{C} \text {. } \\
\text { n.d.: no data. }\end{array}$} \\
\hline
\end{tabular}

by the circulation of drilling fluid to temperatures below formation temperature. They are thus all lower than the undisturbed formation equilibrium values.

The depth intervals over which measurements were made at different times overlap partly. This makes it possible to estimate the size of temperature disturbances and correct for them. The upper part of $\log 4$ overlaps with the lowest part of $\log 2$ in the depth interval $2170-2175 \mathrm{~m}$. $\log 4$ temperatures were here $3.7^{\circ} \mathrm{C}$ below the temperatures of $\log 2$, which are assumed to be undisturbed. The increase in temperature between $\operatorname{logs} 3,4$ and 5 (Fig. 2), combined with additional log data not shown, has been used to estimate the amount of disturbance by Hornertype analysis. In the deepest part of $\log 5$ a temperature of $98.6^{\circ} \mathrm{C}$ was measured at a depth of $3430 \mathrm{~m}, 53$ hours after drilling fluid circulation. Temperatures are estimated to have been reduced by $3-7 \%$, so, applying a correction of $5 \%$, the undisturbed value is about $103.5^{\circ} \mathrm{C}$. In the final selection of temperature data, only the almost
Table 3. Least-squares mean temperature gradients for various depth intervals

\begin{tabular}{lccc}
\hline Log & $\begin{array}{c}\text { Depth interval } \\
(\mathrm{m})\end{array}$ & $\begin{array}{c}\text { Temp.gradient } \\
\left({ }^{\circ} \mathrm{C} / \mathrm{km}\right)\end{array}$ & $\begin{array}{c}\text { Intercept* } \\
\left({ }^{\circ} \mathrm{C}\right)\end{array}$ \\
\hline 2 & $1400-2175$ & 32.9 & -6.7 \\
4 & $2170-2770$ & 30.1 & 0.0 \\
5 & $2995-3430$ & 28.2 & 6.2 \\
$2,4,5$ & $1400-3430$ & 31.4 & -3.9 \\
\hline
\end{tabular}

* Intercept temperature value (linearly extrapolated temperature at zero depth) associated with each depth section.

linear part of $\log 4$ (2170-2775 m, Fig. 2) with corrections between $3.7^{\circ} \mathrm{C}$ (top) and $4.0^{\circ} \mathrm{C}$ (bottom) was used.

After corrections of logs 4 and 5 for the estimated disturbance due to drilling, the corrected temperatures follow the same depth trend as that of the deeper part of log 2. Below $1100 \mathrm{~m}$, measured temperatures on $\log 2$ and the corrected values on logs 4 and 5 fall within $1.2^{\circ} \mathrm{C}$ of a constant gradient least-squares temperature line (Fig. 3). As discussed above, the corrected temperatures on logs 4 and 5 are thought to represent equilibrium temperatures to a good approximation (within $1-3^{\circ} \mathrm{C}$ ) and to be sufficiently accurate to calculate accurate mean temperature gradients for the larger depth intervals. Measured temperatures on $\log 2$ (below $1200 \mathrm{~m}$ ) and corrected values on logs 4 and 5 are listed at $100 \mathrm{~m}$ depth intervals in Table 2 .

\section{Equilibrium temperatures and temperature gradients}

Mean least-squares temperature gradients from selected logs and depth intervals have been calculated and are listed in Table 3. In order to ensure a homogeneous base for the calculation of temperature gradients, all logs were resampled to depth increments of $5 \mathrm{~m}$. Mean gradients show only small variations between 28 and $33^{\circ} \mathrm{C} / \mathrm{km}$. $\log 2$ yields a mean gradient of $32.9^{\circ} \mathrm{C} / \mathrm{km}$ between 1400 and $2175 \mathrm{~m}$ and the combined data from logs 2, 4 and 5 for the depth interval 1400 to $3430 \mathrm{~m}$ yield a temperature gradient of $31.4^{\circ} \mathrm{C} / \mathrm{km}$. This demonstrates an overall very homogeneous thermal gradient structure.

In clear contrast to the above overall small gradient variations, significant local temperature gradient variability is observed. Figure 4 shows running mean least-squares interval temperature gradients (covering 5, 25 and $100 \mathrm{~m}$ depth intervals) derived from the high-resolution $\log 2$ run from surface to $2175 \mathrm{~m}$. 
Fig. 4. Running mean least-squares temperature gradients for 5, 25 and $100 \mathrm{~m}$ depth intervals as indicated. Temperature gradients were taken from the high resolution $\log 2$. The dashed line shows the assumed unperturbed mean background gradient of $32.9^{\circ} \mathrm{C} / \mathrm{km}$ calculated for the depth interval of 1400-2175 m (cf. Table 3). Levels of significant inflow of groundwater into the upper part of the borehole are clearly seen as local gradient maxima. Below about $1250 \mathrm{~m}$, temperatures and temperature gradients are thought to represent generally conductive equilibrium conditions and gradient variability is mostly due to variations in rock thermal conductivity (see also Fig. 5).

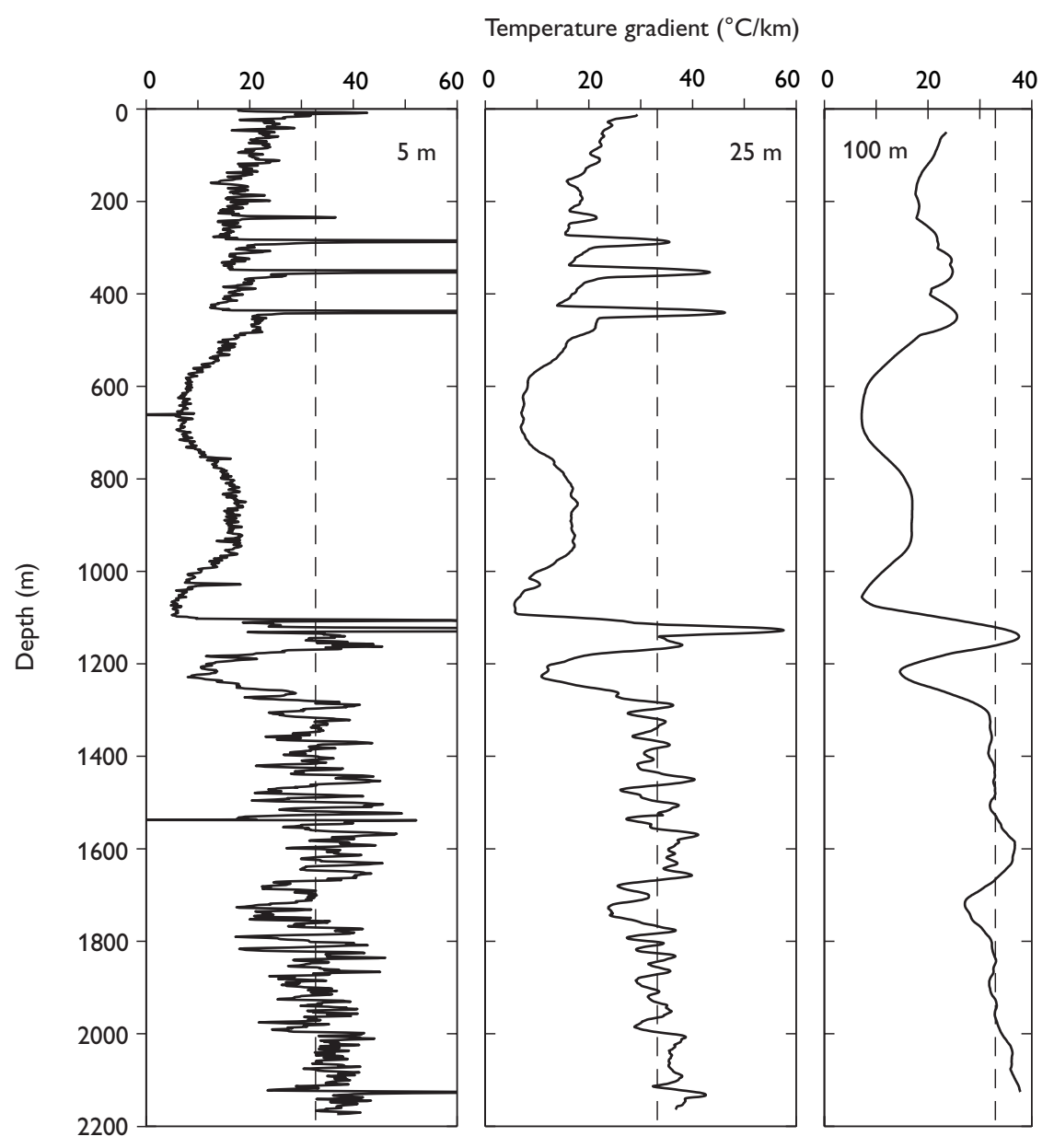

The upper part of the log is disturbed by water flow. The original hole was uncased below $180 \mathrm{~m}$ and water at above hydrostatic pressure was able to enter the hole through local fractures or permeable beds. The temperature and temperature gradient logs combined show clearly levels of significant disturbance due to inflow of water to the borehole. They are characterised by a locally high temperature gradient. Above the level of inflow, both temperature gradients and temperatures are reduced. At the approximate depths of 292, 360, 444, 1111, 1132 and $2130 \mathrm{~m}$, temperature drops of between 0.2 and $0.6^{\circ} \mathrm{C}$ are observed, resulting in locally high temperature gradients. The highest local temperature anomalies of $0.5-0.6^{\circ} \mathrm{C}$ occur at 444 and $1132 \mathrm{~m}$, where also maximal temperature gradient perturbations are observed (Fig. 4). A local minor disturbance is seen around $1538 \mathrm{~m}$ (see also Fig. 5). Most of these thermal perturbations, in particular those above $1100-1200 \mathrm{~m}$, are easily interpreted in terms of inflow of ground water at approximately local formation temperature into a section of the borehole where temperatures are artificially elevated due to upwards-flowing water coming from deeper levels of higher formation temperature. Local lowering of borehole temperature may also occur if water flows downwards through inclined fractures from levels of lower formation temperature to levels of higher formation temperature. However, this does not seem to have happened here.

Longer wavelength temperature-gradient minima are observed at about 550-800 $\mathrm{m}$ and $1160-1250 \mathrm{~m}$ that are not clearly associated with localised zones of inflow of water (Fig. 4). These zones of low gradient may be due to broader zones of water flow into the borehole, perhaps associated with an almost steady migration of ground water within porous or fractured parts of the formation that was initiated long before drilling.

Below 1200-1300 m, the temperature-depth function of $\log 2$ follows the overall almost linear trend of temperature increase with depth (Fig. 3). This trend is overprinted by significant local temperature gradient variations down to the maximum depth of $\log 2$ of $2175 \mathrm{~m}$ (Fig. 4). The local gradient variations are of a different character from those discussed above, but might at first 


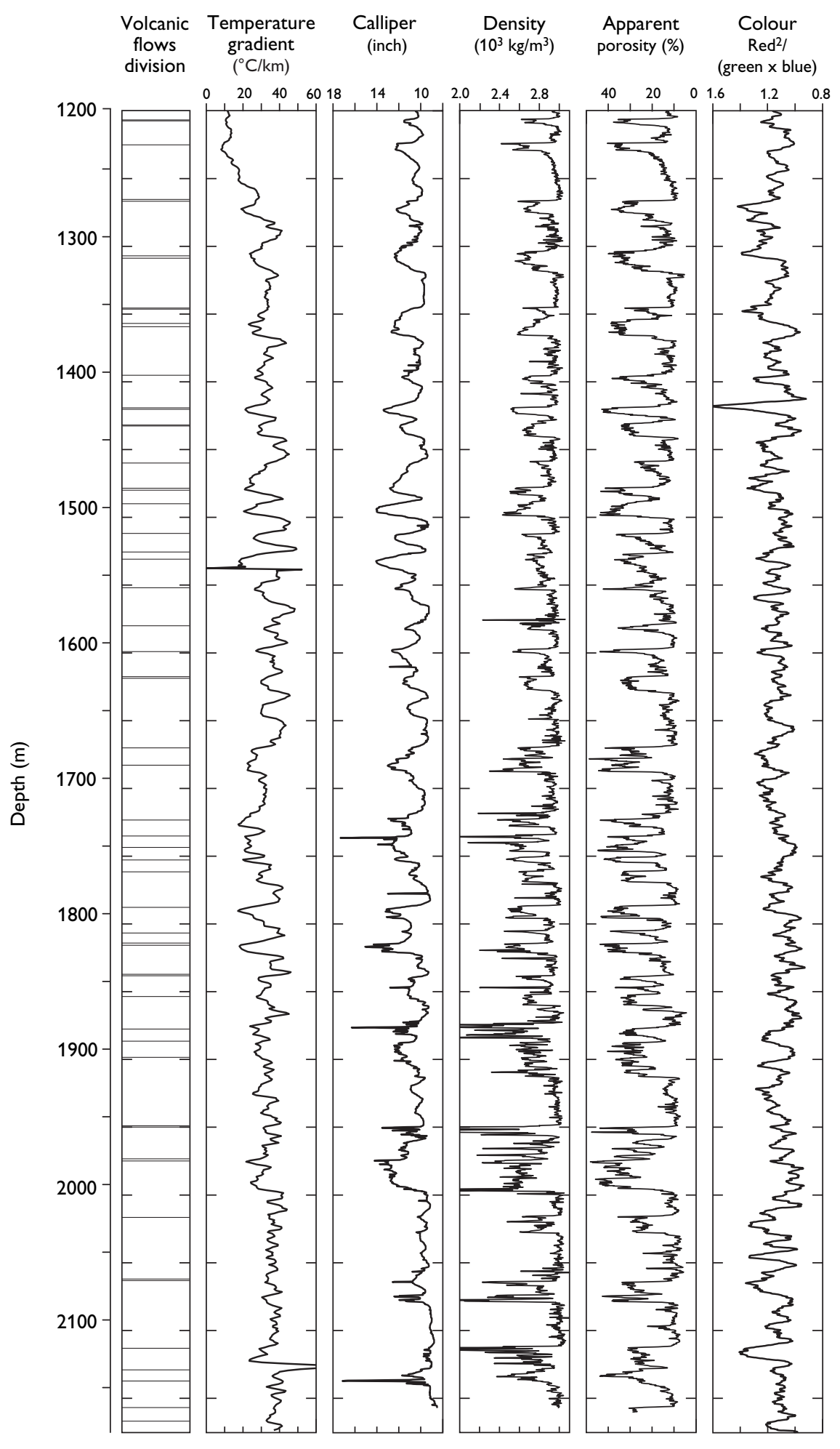

Fig. 5. Running $5 \mathrm{~m}$ mean temperature gradients from $\log 2$ shown together with the calliper, density and neutron porosity logs over the depth interval 1200-2170 m. The left-hand column shows the interpreted volcanic flow boundaries (Hald \& Waagstein 1984) with closely spaced lines generally indicating thin beds of sediment and the right-hand column shows the relative intensity of red measured from cuttings. See text for further details. Note the reversed scale for calliper, apparent porosity and colour. 
sight indicate similar disturbances from flow of water. However, a detailed comparison between temperature gradient variability and other petrophysical log characteristics, including density and neutron porosity logs as well as calliper log data, shows remarkable correlations beginning at a depth of 1250-1300 m (Fig. 5). Mean least-squares temperature gradients based on $5 \mathrm{~m}$ averaging intervals reveal local maximum gradients of up to $40-45^{\circ} \mathrm{C} / \mathrm{km}$ and local minimum values down to $20-25^{\circ} \mathrm{C} / \mathrm{km}$. Local intervals of high temperature gradient correlate with intervals of high density, low neutron porosity and decreased calliper. Intervals of low temperature gradient correlate with intervals of low density, high neutron porosity and increased calliper. The correlation between temperature gradient variability and short-range variations in borehole calliper is particularly remarkable. Maximum temperature gradient variability and close correlations are most pronounced around $1450-1550 \mathrm{~m}$ and $1750-1850 \mathrm{~m}$, but a good general correlation with the physical properties of the various basaltic flow units is observed for most of the depth range shown in Fig. 5.

A correlation of low calliper with increased temperature gradients cannot be explained by potential water flow inside the borehole at these greater depths. Any flow of water would have the opposite effect of lowering gradients in narrow parts of the borehole due to locally increased flow rates. Above a depth of about $1200 \mathrm{~m}$ no correlation is observed. Here temperature gradients seem to be controlled by the flow of water. The temperature gradient variations below about $1250 \mathrm{~m}$ consequently need to be explained in terms of a linkage between resistance to the drill bit, the mineralogical composition and structure and bulk rock thermal properties of the formation. These observed correlations and the inferred variations in rock thermal conductivity are discussed in detail below.

\section{Influence of palaeoclimate}

Surface temperature variations penetrate into the subsurface, and temperature and temperature gradient measurements from boreholes may be used to extract information on short-term as well as long-term surface palaeoclimatic temperature variations (e.g. Dahl-Jensen et al. 1998; Huang et al. 2000; Kukkonen \& Joeleht 2003). The Lopra-1/1A borehole is not particularly well-suited for such purpose due to disturbances of the upper part of the hole by water flow. We shall not, therefore, go into detail, but deal only with some main effects of long-term climatic variations.

Simple linear extrapolation of the temperature-depth function from the deeper parts of the borehole to the surface yields a negative intercept temperature of $-3.9^{\circ} \mathrm{C}$ for the depth interval of $1400-3430 \mathrm{~m}$ and of $-6.7^{\circ} \mathrm{C}$ for the interval 1400-2175 m (Fig. 3 and Table 3). The low intercept temperatures indicate that temperatures in the deeper parts of the borehole are in equilibrium with a surface temperature significantly below the present-day mean ground temperature of about $7^{\circ} \mathrm{C}$. This simple linear extrapolation of deep mean temperature gradients seems justified in our preliminary study because of the apparent homogeneity of mean thermal conductivity and temperature gradients over large depth intervals (see also next section). The shorter intervals of 2175-2770 $\mathrm{m}$ and 2995$3430 \mathrm{~m}$ give higher intercept values, but these are considered uncertain because of the short length of the intervals that make the extrapolation more sensitive to local variations in thermal conductivity.

Forward thermal modelling using a thermal diffusivity of basalt of $0.7 \times 10^{-6} \mathrm{~m}^{2} / \mathrm{s}$ shows that long-term surface temperature variations of the magnitude associated with glaciation and deglaciation are reduced in amplitude to less than $1-2^{\circ} \mathrm{C}$ (depending on surface temperature amplitudes) at depths below 1300-1500 m. The most accurate temperature gradient and temperature intercept value is probably that from the depth interval 1400-2175 $\mathrm{m}$. Since porosity is likely to decrease with depth, porosities in the rocks sampled by the upper part of the borehole may on average be slightly greater than in those sampled by the deeper parts. This could point towards a slightly lower thermal conductivity and hence a slightly higher temperature gradient at shallow depths. This effect may, however, be more or less cancelled by secondary mineralisation, which tends to increase the conductivity of porous sections. This means that the mean characteristic conductivity of the upper $1400 \mathrm{~m}$ may not differ much from that of the interval $1400-2175 \mathrm{~m}$, justifying the extrapolation with a constant gradient.

We may thus interpret the surface intercept temperature of $-6.7^{\circ} \mathrm{C}$ as an estimate of the long-term characteristic mean for the cold period of the last glaciation. We estimate the increase in surface temperature associated with the termination of the last glaciation to be of the order of $12-16^{\circ} \mathrm{C}$. This is a preliminary estimate considering the approximate nature of our procedure, uncertainties related to the lack of good temperature data from the upper part of the borehole (which prevents extraction of a detailed past temperature-time function) and uncertainties related to possible vertical variations in thermal conductivity.

A more detailed analysis of this problem, including inverse modelling, must be based on thermal information from other boreholes, in particular from near-surface in- 
tervals where the Lopra-1/1A borehole is disturbed thermally. This is beyond the scope of this paper. From inverse analyses of the temperature-depth function from the GRIP-borehole on the Greenland ice sheet, Dahl-Jensen et al. (1998) calculated a surface-temperature increase of $23^{\circ} \mathrm{C}$ following the last glacial maximum. Using a similar procedure on many boreholes, Kukkonen \& Joeleht (2003) obtained an average warming of $8^{\circ} \mathrm{C}$ for NW Europe at the termination of the last glaciation.

The deviation in the upper part of the Lopra-1/1A borehole from the general linear trend of temperatures deeper down (Fig. 3) thus has two main causes. The increase at surface level from about $7^{\circ} \mathrm{C}$ to the measured borehole temperature at surface of about $12^{\circ} \mathrm{C}(\log 2)$ is due to the upward flow of warm water inside the borehole. The remaining part, the increase from negative intercept values to about $7^{\circ} \mathrm{C}$, is interpreted to reflect the increase of temperature at around the termination of the last glacial period. The penetration of this heating effect to a depth of about $1200 \mathrm{~m}$ (Fig. 3) is in agreement with model calculations. Unfortunately, this depth level is also the approximate level above which temperatures and temperature gradients are significantly disturbed from the flow of water inside the borehole.

\section{Thermal conductivity}

A limited amount of suitable sample material was available for thermal conductivity measurements. Only one conventional core was drilled within the deepened section below $2175 \mathrm{~m}$. However, a few rotary sidewall cores were also long enough to be measured. Including published measurements on four cored sections from the original borehole, a total of 11 samples have been measured covering the depth range of 337 to $3531 \mathrm{~m}$ (driller's depths). Rock materials measured represent massive basalt (7 samples), lapilli-tuff (3 samples) and tuff (1 sample). In addition to thermal conductivity, rock density and porosity were also measured. Measuring results on samples from the Lopra-1/1A borehole are summarised in Table 4. Supplementary preliminary conductivity measurements were additionally carried out on 14 samples taken from surface exposures of basalts near the borehole.

\section{Measuring techniques}

Both the needle-probe transient line source technique and the steady-state divided bar technique were applied to measure thermal conductivity. These are standard techniques

Table 4. Measured thermal conductivity, porosity and density and calculated matrix (grain) thermal conductivity and density

\begin{tabular}{|c|c|c|c|c|c|c|c|}
\hline Sample & $\begin{array}{l}\text { Rock } \\
\text { type }\end{array}$ & $\begin{array}{l}\text { Depth* } \\
\text { (m) }\end{array}$ & $\begin{array}{c}\text { Thermal } \\
\text { conductivity } \\
\left(\mathrm{W} / \mathrm{m}^{\circ} \mathrm{C}\right)\end{array}$ & $\begin{array}{c}\text { Matrix } \\
\text { thermal } \\
\text { conductivity } \\
\left(\mathrm{W} / \mathrm{m}^{\circ} \mathrm{C}\right)\end{array}$ & $\begin{array}{c}\text { Porosity } \\
\text { (\%) }\end{array}$ & $\begin{array}{c}\text { Bulk } \\
\text { density } \\
\left(10^{3} \mathrm{~kg} / \mathrm{m}^{3}\right)\end{array}$ & $\begin{array}{c}\text { Matrix } \\
\text { density } \\
\left(10^{3} \mathrm{~kg} / \mathrm{m}^{3}\right)\end{array}$ \\
\hline $\mathrm{C}_{1 \dagger}{ }^{\circ}$ & basalt & 337.5 & 1.75 & 1.81 & 3.0 & 2.96 & 3.02 \\
\hline $\mathrm{C} 2$ & basalt & 860.1 & 1.85 & 1.95 & 4.5 & 2.98 & 3.07 \\
\hline $\mathrm{C} 3$ & basalt & 1218.1 & 1.74 & 1.80 & 3.0 & 2.94 & 3.00 \\
\hline C4 & basalt & 2177.3 & 1.79 & 1.82 & 1.7 & 3.00 & 3.03 \\
\hline C5 & basalt & 2380.0 & 1.79 & 1.85 & 2.7 & 3.00 & 3.06 \\
\hline Swc 46‡ & basalt & 2441.0 & 1.87 & 1.96 & 3.9 & 2.93 & 3.01 \\
\hline Swc 37 & lapilli-tuff & 2562.0 & 1.35 & 1.60 & 17.3 & 2.47 & 2.78 \\
\hline Swc 13 & lapilli-tuff & 3438.0 & 1.88 & 2.29 & 14.8 & 2.76 & 3.07 \\
\hline Swc 6 & tuff & 3512.5 & 1.91 & 2.17 & 9.9 & 2.78 & 2.98 \\
\hline Swc 5 & lapilli-tuff & 3514.5 & 1.93 & 2.27 & 12.1 & 2.68 & 2.91 \\
\hline Swc 4 & basalt & 3531.0 & 1.84 & 1.90 & 2.7 & 3.10 & 3.16 \\
\hline \multicolumn{3}{|c|}{ Mean values, all samples (11) } & 1.79 & 1.95 & 6.9 & 2.87 & 3.01 \\
\hline \multicolumn{3}{|c|}{ Standard deviation } & 0.16 & 0.21 & 5.6 & 0.18 & 0.10 \\
\hline \multicolumn{3}{|c|}{ Mean values, basalt $(7)$} & 1.80 & 1.87 & 3.1 & 2.99 & 3.05 \\
\hline \multicolumn{3}{|c|}{ Standard deviation } & 0.05 & 0.07 & 0.9 & 0.06 & 0.05 \\
\hline \multicolumn{3}{|c|}{ Mean values, lapilli-tuff/tuff (except outlier Swc 37) (3) } & 1.91 & 2.24 & 12.3 & 2.74 & 2.99 \\
\hline \multicolumn{3}{|c|}{ Standard deviation } & 0.03 & 0.06 & 2.5 & 0.06 & 0.08 \\
\hline
\end{tabular}

* Driller's depth below rotary table (to top of core).

† Samples C1 to C5 are from conventional cores taken during drilling.

† The Swc samples are small rotary sidewall cores taken after drilling. 
for laboratory rock thermal conductivity measurements (e.g. Beck 1988). All measurements were carried out in the geophysical laboratories of the University of Aarhus. Equipment and measuring procedures were similar to those described in Balling et al. (1981).

Most rock materials from the deepened section of the borehole and from surface exposures were measured by the needle probe technique. The needle probes used have a nominal length of $50 \mathrm{~mm}$ and an outer diameter of 1.5 $\mathrm{mm}$. The measured sidewall cores are cylindrical with a diameter of about $24 \mathrm{~mm}$ and lengths ranging from 18 to $30 \mathrm{~mm}$. The probe length cannot be reduced significantly since interpretation is based on line source approximations. The probe length thus exceeds that of the samples to be measured. This difficulty was largely overcome by placing the rock sample of unknown conductivity along the critical central position of the needle probe where the temperature rise function is measured and extending the sample by 'end materials' of known conductivity close to that of the material to be measured. By iterative trial and error procedure, the difference between conductivity of end materials and conductivity of rock sample was reduced to less than $0.3 \mathrm{~W} / \mathrm{m}{ }^{\circ} \mathrm{C}$. Experience suggests that this is sufficiently small for an accurate sample conductivity measurement. Any further boundary effects due to the small size of samples were minimised by immersing the samples in water-saturated sand with conductivity close to that of the rock samples being measured.

All samples were water-saturated under vacuum before measurement, which was carried out at normal laboratory temperature (about $20^{\circ} \mathrm{C}$ ) and pressure ( $1 \mathrm{~atm}$.) conditions. All needle probes were calibrated and tested by measurement of standard materials of known thermal conductivity. The heating period for the probes was 40-60 seconds and the temperature rise at probe centre typically $2-4^{\circ} \mathrm{C}$. Sample conductivity was determined as a mean value of at least three individual measurements and individual measurements on the same sample generally did not differ by more than 3-5\%. The unknown thermal conductivity was calculated from the temperature rise data using the iterative least-squares inversion technique of Kristiansen (1991).

Samples c1 to c5 (Table 4) were originally measured by the divided bar technique and the results were reported in Balling et al. (1984). These older measurements seem to be somewhat too low. A comparison of new needle probe measurements with old divided bar measuring results on material from the same basalt cores shows that the old measurements are systematically about $15 \%$ too low. The older low results seem due to the small dimensions of the samples. Previous measurements are thus corrected by +
$15 \%$. Considering all sources of experimental uncertainty, reported conductivity values are estimated to be accurate to $\pm 0.1 \mathrm{~W} / \mathrm{m}{ }^{\circ} \mathrm{C}$.

Rock bulk density of water saturated samples and porosity were measured on all samples. Density was measured by using the Archimedes principle of buoyancy. Weight of samples in air and immersed in water, respectively, yields sample weight and volume. Porosity was determined by measuring loss of weight of the water-saturated samples when drying them at about $110^{\circ} \mathrm{C}$ for $1-2$ days. Repeated determinations of porosity on selected samples suggest a precision of $\pm 1 \%$ for low porosity samples $(2-5 \%)$ and $\pm 1-2 \%$ for samples of higher porosity (10-20\%).

With known porosity, bulk density and bulk thermal conductivity, the solid matrix (grain) density and thermal conductivity may be estimated. The computation of matrix density is straightforward assuming proportional contribution of solid matrix and water. Matrix thermal conductivity was computed from the geometric mean formula relating bulk conductivity, $\mathrm{k}_{\mathrm{b}}$, matrix conductivity, $\mathrm{k}_{\mathrm{m}}$, conductivity of water, $\mathrm{k}_{\mathrm{w}}$, and porosity (pore fraction), $\varphi$, by $\mathrm{k}_{\mathrm{b}}=\mathrm{k}_{\mathrm{m}}^{(1-\varphi)} \mathrm{k}_{\mathrm{w}}^{\varphi}$. Bulk conductivity and porosity are measured. The conductivity of water at room temperature is $0.6 \mathrm{~W} / \mathrm{m}{ }^{\circ} \mathrm{C}$.

\section{Measuring results}

Thermal conductivity measuring results are listed together with the density and porosity determinations in Table 4. Mean values and standard deviations were calculated for all 11 samples, for the basalts alone (seven samples) and for lapilli-tuff/tuffalone (three samples, excluding the sample swc 37). Variations between samples are small. All basalts are oflow porosity $(<5 \%)$ and the conductivity is within the range of $1.75-1.87 \mathrm{~W} / \mathrm{m}^{\circ} \mathrm{C}$ with a well defined mean value of $1.80 \mathrm{~W} / \mathrm{m}{ }^{\circ} \mathrm{C}$. The lapilli-tuff and tuff samples have higher porosity $(10-17 \%)$ and show a wider range of conductivity, between 1.35 and $1.93 \mathrm{~W} / \mathrm{m}{ }^{\circ} \mathrm{C}$. Except for sample swc 37, the lapilli-tuff/tuff samples have a higher solid matrix conductivity than the basalts. Omitting swc 37 , mean matrix conductivity of lapilli-tuff and tuff is $2.24 \mathrm{~W} / \mathrm{m}{ }^{\circ} \mathrm{C}$ as compared to $1.87 \mathrm{~W} / \mathrm{m}^{\circ} \mathrm{C}$ for basalt. This difference in matrix conductivity explains why lapillituff and tuff have slightly higher conductivity than basalt despite a higher porosity and higher content of free water of low conductivity. The anomalous sample swc 37 has the highest porosity (17.3\%) and lowest bulk and matrix conductivity measured. This is possibly due to the presence of a significant amount of secondary analcite, a mineral of very low conductivity $\left(1.3 \mathrm{~W} / \mathrm{m}^{\circ} \mathrm{C}\right)$ (Horai 1971). 
The thermal conductivity measurements on core materials from the Lopra-1/1A borehole have been supplemented by preliminary measurements of samples of basalts taken from surface exposures in the local area of the borehole. A total of 14 samples were measured. Measurements were again carried out on water-saturated samples using the needle probe technique. Eight samples of low porosity $(\leq 4 \%)$ have a mean conductivity of $1.77 \mathrm{~W} / \mathrm{m}^{\circ} \mathrm{C}$ (range $1.67-1.86 \mathrm{~W} / \mathrm{m}^{\circ} \mathrm{C}$ ) and six samples of higher porosity (porosity range $5-26 \%$ and mean porosity $13 \%$ ) have a mean of $1.51 \mathrm{~W} / \mathrm{m}^{\circ} \mathrm{C}$ (range $1.38-1.59 \mathrm{~W} / \mathrm{m}^{\circ} \mathrm{C}$ ). The conductivity of low-porosity basalts is thus well defined, having a value of about $1.8 \pm 0.1 \mathrm{~W} / \mathrm{m}{ }^{\circ} \mathrm{C}$. Conductivity decreases with increasing porosity due to the presence of water of low conductivity. Details of these measurements are not shown, but the results conform well to and supplement those from the borehole samples.

\section{Other studies}

Our conductivity results on basalts agree well with results obtained by others. Oxburgh \& Agrell (1982) measured more than one hundred samples of basaltic flows, intrusions and breccias covering the full depth range of the 2 $\mathrm{km}$ deep Reydarfjordur borehole in eastern Iceland. Their measurements on water-saturated samples show increasing thermal conductivity with decreasing porosity and increasing sample depth. Single measurements from basaltic flows and intrusions range between 1.4 and $2.2 \mathrm{~W} / \mathrm{m}$ ${ }^{\circ} \mathrm{C}$. Mean values over $500 \mathrm{~m}$ intervals increased with depth from about 1.6 in the upper part of the borehole to 1.7$1.9 \mathrm{~W} / \mathrm{m}{ }^{\circ} \mathrm{C}$ in the central and deeper part of the hole. Measurements on 17 rock samples classified as breccias showed the highest values of conductivity and the widest spread, $1.6-2.8 \mathrm{~W} / \mathrm{m}{ }^{\circ} \mathrm{C}$.

As part of heat-flow measurements in shallow boreholes in the south-eastern part of the Deccan Volcanic Province, central India, Roy \& Rao (1999) measured thermal conductivity on about 25 core samples of basalt and several samples of fresh massive basalt from outcrops. They obtained sample values within the narrow range of 1.6$1.8 \mathrm{~W} / \mathrm{m}{ }^{\circ} \mathrm{C}$ with a well-defined mean value of about 1.7 $\mathrm{W} / \mathrm{m}{ }^{\circ} \mathrm{C}$.

The same range of measured thermal conductivity is found in the large dataset of Robertson \& Peck (1974) on basalts from Hawaii for water-saturated samples oflow porosity (2\% to about $10 \%)$ and low olivine content $(0-5 \%)$. With increasing porosity and pore-water content, conductivity decreased significantly and variations in mineral content played an important role (see also Horai 1991).

\section{Conductivity variations at Lopra-1/1A and their causes}

In a conductive steady-state geothermal regime, variations of the temperature gradient are related to variations in rock thermal conductivity. Intervals of high thermal conductivity result in low temperature gradients and intervals of low thermal conductivity result in high temperature gradients. This simple inverse relation follows from Fourier's law of heat conduction, which relates heat flow to the product of thermal conductivity and temperature gradient. For depth sections of low heat production, conductive heat flow is almost constant and temperature gradient variations will reflect variations in rock thermal conductivity.

Water has a thermal conductivity of $0.6 \mathrm{~W} / \mathrm{m}{ }^{\circ} \mathrm{C}$, which is much less than a rock matrix of overall basaltic composition with a mean conductivity around $2 \mathrm{~W} / \mathrm{m}^{\circ} \mathrm{C}$. Significant variations in porosity of the basalt will therefore result in major conductivity variations and associated variations in conductive temperature gradient. Thermal conductivity will decrease with increased content of pore water and the temperature gradient will increase. We observe that sections of high neutron porosity are intervals of local low temperature gradient (Fig. 5). This means that a significant part of the water in rocks of apparent high porosity must be bound in water-bearing secondary minerals. Furthermore, some of the secondary minerals (water-free or not) must have a thermal conductivity significantly above that of the mean value of the minerals of unaltered basalt.

Maximum temperature gradients are generally observed within the massive (non-porous) cores of basalt flows, which are characterised by high density and low neutron porosity (Fig. 5). This mainly reflects the presence of feldspar, a primary igneous minerals of low conductivity. However, secondary minerals of even lower conductivity must be present as well.

The large local conductive temperature gradient variations observed between about 1250 and $2175 \mathrm{~m}$ (Figs 4, 5) are thus interpreted to originate from significant vertical variations in mean thermal conductivity. In order to maintain a constant heat flow of around $60 \mathrm{~mW} / \mathrm{m}^{2}$ (see next section), local intervals of minimum temperature gradient of $20-25^{\circ} \mathrm{C} / \mathrm{km}$ must indicate conductivities within the approximate range of $2.5-3.0 \mathrm{~W} / \mathrm{m}^{\circ} \mathrm{C}$, and local intervals of maximum temperature gradients of about $45^{\circ} \mathrm{C} /$ $\mathrm{km}$ must indicate conductivities around $1.3-1.4 \mathrm{~W} / \mathrm{m}{ }^{\circ} \mathrm{C}$. The thickness of lithological units of maximum temperature gradient variations and inferred maximum conductivity variations is typically in the range of 5-20 m (Fig. 5). 
Such variations of rock thermal conductivity by a factor of about two are not directly represented in our set of conductivity measurements (Table 4). A potential for variation is, however, indicated by the observation that the mean solid matrix conductivity of lapilli-tuff and tuff is $20 \%$ higher than that of basalt. Zones of inferred increase of conductivity are observed to be closely related to zones of reduced density in the originally porous part of the basalt flows. This may be explained by the presence of secondary minerals of high conductivity. The secondary filling of pores, voids and cracks must include minerals of thermal conductivity significantly above that of normal basalt matrix with a conductivity around $2 \mathrm{~W} / \mathrm{m}{ }^{\circ} \mathrm{C}$.

This interpretation is consistent with observations of Oxburgh \& Agrell (1982) who found that thermal conductivity in the Reydarfjordur borehole generally increased with the degree of alteration, with the highest conductivity of up to $2.8 \mathrm{~W} / \mathrm{m}^{\circ} \mathrm{C}$ occurring in rock samples broadly classified as breccias.

In general, the thin sediment intervals occur within the broader intervals of low temperature gradient (Fig. 5), indicating a mean thermal conductivity of the sediments very close to that of the adjacent basalt flows. Values of thermal conductivity quoted below are mostly from the comprehensive study and listing of conductivity of rock forming minerals by Horai (1971). High-conductivity secondary minerals present locally in variable amounts in the Reydarfjordur borehole include calcite $\left(3.4 \mathrm{~W} / \mathrm{m}^{\circ} \mathrm{C}\right)$, chlorite $\left(4-6 \mathrm{~W} / \mathrm{m}^{\circ} \mathrm{C}\right)$, quartz $\left(7.7 \mathrm{~W} / \mathrm{m}{ }^{\circ} \mathrm{C}\right)$, epidote (2.6-3.0 W/m ${ }^{\circ} \mathrm{C}$ ) and haematite (about $11 \mathrm{~W} / \mathrm{m}^{\circ} \mathrm{C}$ ). In the Lopra-1/1A borehole, zones of maximum temperature gradient and inferred minimum mean conductivity are generally found within the massive cores of the basalt flows characterised by high density and low porosity (Fig. 5). This clearly points to a local increase in low-conductivity secondary minerals such as clay minerals (about 1.5$\left.2 \mathrm{~W} / \mathrm{m}{ }^{\circ} \mathrm{C}\right)$, analcite $\left(1.3 \mathrm{~W} / \mathrm{m}{ }^{\circ} \mathrm{C}\right)$ and hydrous zeolite minerals like stilbite $\left(1.2 \mathrm{~W} / \mathrm{m}^{\circ} \mathrm{C}\right)$.

In order to take a step further into the analysis of the temperature-gradient variability related to mineralogical variations, Fig. 5 also presents a curve showing the relative intensity of red colour reflected from the formation. The colour information is extracted from a digital colour photograph with 24-bit resolution of a montage of cutting samples from the borehole (using the public domain program ImageJ). The relative intensity of red is computed from the values of the red, green and blue channels as the function $\mathrm{red}^{2} /$ (green $\times$ blue). The main idea is to test without extensive mineralogical analysis whether the mineral haematite might play an important role. Haematite $\left(\mathrm{Fe}_{2} \mathrm{O}_{3}\right)$ has a bright reddish colour and very high thermal conductivity. It is formed mainly by oxidation of primary magnetite and secondary iron hydroxides. The colour curve shows that many intervals of maximum reddish colour more or less coincide with intervals of low temperature gradient. A close correlation is seen particularly within the depth interval $1550-1700 \mathrm{~m}$. An average cuttings lag time correction of $3 \mathrm{~m}$ is applied for the whole section. However, the lag varies with drilling rate, which varies with the hardness of the formation, and a locally better correlation may be obtained by applying a slightly different depth shift of the colour curve.

From the continuously cored Vestmanna-1 borehole, also in the Faroe Islands, the content of haematite in highly oxidised tuffaceous claystone may be as high as $25 \%$ estimated from bulk rock chemistry (unpublished data, R. Waagstein). A unit of highly altered basalt or tuff consisting of silicate minerals like pyroxene, plagioclase, clay and zeolites with an assumed average matrix thermal conductivity of about $2 \mathrm{~W} / \mathrm{m}{ }^{\circ} \mathrm{C}$ plus $25 \%$ of haematite (conductivity about $11 \mathrm{~W} / \mathrm{m}^{\circ} \mathrm{C}$ ) will have a bulk conductivity of about $3 \mathrm{~W} / \mathrm{m}{ }^{\circ} \mathrm{C}$, as calculated using the geometric mean formula, (see above). This is sufficiently high to produce the lowest temperature gradients of about $20^{\circ} \mathrm{C} / \mathrm{km}$. Nonetheless, units of increased thermal conductivity generally also have a high (apparent) neutron porosity, which requires minerals of high hydrogen content. This means that, although haematite may play an important part, other components are contributing and further studies are needed for a better understanding of the relation between rock thermal properties and secondary mineralogical components.

\section{Estimates of heat flow}

Basalts have low concentrations of the heat producing isotopes $\mathrm{U}$, Th and $\mathrm{K}$, resulting in low heat production, generally within the range of $0.2-0.6 \times 10^{-6} \mathrm{~W} / \mathrm{m}^{3}$ (e.g. Verdoya et al. 1998; Chiozzi et al. 2003). The contribution to surface heat flow from a $3.5 \mathrm{~km}$ deep section is thus very small, of the order of $1-2 \mathrm{~mW} / \mathrm{m}^{2}$. If not significantly perturbed by effects of topography, groundwater flow or potential long-term palaeoclimatic surface-temperature variations, heat flow should be almost constant along the drilled section. For sections of the Lopra-1/1A borehole where temperature measurements are assumed to represent conductive equilibrium values, heat flow may therefore be estimated from the product of mean temperature gradient and mean characteristic thermal conductivity.

There seems to be no significant perturbing effects at depths below $1300 \mathrm{~m}$. The Lopra-1/1A borehole is in an 
area of small topographic height variations and the effect of topography upon temperature and temperature gradient was modelled to be insignificant. Temperature perturbations are below $1^{\circ} \mathrm{C}$. The artesian flow of water in the borehole is localised to levels above $1150-1200 \mathrm{~m}$. As discussed above, both observations and model calculations show that the influence of palaeoclimatic surface temperature variations is insignificant at depths greater than 1200 $1300 \mathrm{~m}$.

Mean temperature gradients from long depth intervals vary within the narrow range of $28-33^{\circ} \mathrm{C} / \mathrm{km}$ (Table 3 ) and are thus well defined. The main source of error in estimating heat flow is thus the choice of mean characteristic thermal conductivity. The uncertainty arises from the presence of local variations of the temperature gradient interpreted in the previous section in terms of conductivity variations associated with mineralogical changes. These changes are difficult to quantify in detail and thus not fully understood.

By transferring thermal conductivity from laboratory measurements to representative in situ values, temperature and pressure dependency needs consideration. However, for basalt this dependency is small compared to most other crystalline rocks. The decrease of thermal conductivity of basalt with increasing temperature is of the order of only $5-10 \%$ for a temperature increase from $20^{\circ} \mathrm{C}$ in the laboratory to a temperature of $50-100^{\circ} \mathrm{C}$ in a borehole (cf. compilations in Kappelmeyer \& Haenel 1974). A conductivity decrease of this magnitude is likely to be almost compensated by an equivalent increase of conductivity with pressure. The slightly lower temperature gradient in the deeper parts of the borehole (Table 3) may indicate a slight general increase in average thermal conductivity with depth. This increase may be explained by decreasing porosity resulting from secondary mineralisation.

The most accurate large interval temperature gradient is the assumed conductive mean equilibrium gradient of $32.9^{\circ} \mathrm{C} / \mathrm{km}$ between 1400 and $2175 \mathrm{~m}$. Using our rock thermal conductivity measurements in the range of $1.7-$ $1.9 \mathrm{~W} / \mathrm{m}{ }^{\circ} \mathrm{C}$ with a mean of about $1.8 \mathrm{~W} / \mathrm{m}{ }^{\circ} \mathrm{C}$, we obtain a heat flow within the range of $56-63 \mathrm{~mW} / \mathrm{m}^{2}$. For the deeper parts of the borehole between 2200 and 3430 $\mathrm{m}$, the temperature gradient is between 30 and $31^{\circ} \mathrm{C} / \mathrm{km}$. The lithology is here represented by roughly equal amounts of basalt and lapilli-tuff. Low-porosity lapilli-tuff may have a mean conductivity of about $2.0-2.2 \mathrm{~W} / \mathrm{m}^{\circ} \mathrm{C}$ and basalt of about 1.8 to $1.9 \mathrm{~W} / \mathrm{m}^{\circ} \mathrm{C}$. This yields a mean conductivity of about $2.0 \mathrm{~W} / \mathrm{m}^{\circ} \mathrm{C}$ and a heat-flow estimate close to $60 \mathrm{~mW} / \mathrm{m}^{2}$.

Some local intervals of massive basalt at depths between 2000 and 2115 m have well-defined temperature gradients between 35 and $38^{\circ} \mathrm{C} / \mathrm{km}$ with a mean value of $36^{\circ} \mathrm{C} / \mathrm{km}$. Although massive basalt units are inferred to have a slightly reduced conductivity judged by their temperature gradients, average conductivity (inferred from our measurements) seems unlikely to be lower than 1.6 and not above $1.8 \mathrm{~W} / \mathrm{m}{ }^{\circ} \mathrm{C}$, resulting in heat flow in the range $57-65$ $\mathrm{mW} / \mathrm{m}^{2}$.

Despite some uncertainty about details of the conductivity variations and their causes, we therefore estimate terrestrial heat flow for the Lopra-1/1A borehole to be of the order $60 \pm 5 \mathrm{~mW} / \mathrm{m}^{2}$. This value is about $15 \mathrm{~mW} / \mathrm{m}^{2}$ higher than a previous estimate of Balling et al. (1984). The main reason is new measurements showing higher values of thermal conductivity and also the recognition that the neutron log data cannot be interpreted in terms of intervals of real high porosity and water-filled pores resulting in reduced thermal conductivity. On the contrary, local intervals of apparent high porosity are generally observed as having low temperature gradients and thus increased thermal conductivity.

Nearby areas of continental crust in the Faroe-Shetland Basin south-east of the Faroe Islands have presentday heat flows between 45 and $65 \mathrm{~mW} / \mathrm{m}^{2}$ (Iliffe et al. 1999). In continental areas off the Norwegian coast, mean heat flow is between 50 and $65 \mathrm{~mW} / \mathrm{m}^{2}$ (Sundvor et al. 2000). A heat flow value of around $60 \mathrm{~mW} / \mathrm{m}^{2}$ is thus consistent with continental crust underlying the Faroe Islands. Heat flow from the mantle in Scandinavia is estimated to be around $25-35 \mathrm{~mW} / \mathrm{m}^{2}$ (Balling 1995). If similar values apply here, about $30 \mathrm{~mW} / \mathrm{m}^{2}$ must originate from heat produced by decay of radiogenic isotopes in the crust, which requires a crust of continental composition. Otherwise, a significant cooling component and/ or significantly increased mantle heat flow must be assumed, for which there is no other evidence. However, this must be the case for areas of oceanic crust north of the Faroe Islands, where heat flow generally between 60 and $75 \mathrm{~mW} / \mathrm{m}^{2}$ is observed (Sundvor et al. 2000).

\section{Summary and conclusions}

The Lopra-1/1A borehole drilled to a depth of $3.5 \mathrm{~km}$ offers a unique opportunity of obtaining accurate information on the thermal structure to a great depth in the Faroe Islands. High-precision temperature logging was carried out to a depth of $2175 \mathrm{~m}$ almost 13 years after drilling. Temperatures in the upper 1200-1300 m are significantly disturbed by upward flow of ground water inside the borehole. For deeper levels, between $2175 \mathrm{~m}$ and total depth, only temperature logs from the commercial log- 
ging runs measured a relatively short time (up to 53 hours) after drilling fluid circulation are available. These temperatures have been corrected for the estimated effect of disturbances. The deepest point of accurate temperature information is $3430 \mathrm{~m}$ with a measured temperature of $98.6^{\circ} \mathrm{C}$ and a corrected, estimated equilibrium temperature of $103.5^{\circ} \mathrm{C}$.

Temperature gradients calculated for depth intervals greater than $500-1000 \mathrm{~m}$ show only small variations between 28 and $33^{\circ} \mathrm{C} / \mathrm{km}$. The least-squares mean gradient for the undisturbed part of the borehole (1400-3430 m) is $31.4^{\circ} \mathrm{C} / \mathrm{km}$. Levels of inflow of water to the upper part of the borehole are seen as major peaks on the $5 \mathrm{~m}$ mean interval temperature gradient. In addition, significant local temperature gradient variability is observed in the highprecision log between about $1250 \mathrm{~m}$ with minimum values down to $20-25^{\circ} \mathrm{C} / \mathrm{km}$ and maximum values up to $45^{\circ} \mathrm{C} /$ $\mathrm{km}$. The latter variations correlate closely with variations in other logging parameters and inferred lithological variations within the lava succession and cannot be explained by ground-water flow. Intervals of low temperature gradient generally match intervals of low density, high neutron porosity and increased borehole calliper and intervals of high temperature gradients match intervals of high density, low neutron porosity and decreased calliper.

The observed correlation with neutron porosity is surprising. In a conductive regime, the temperature gradient should increase in lithological units of high porosity and pores filled with free water of low thermal conductivity. Here, we observe that units of apparent high porosity have high gradients. This leads us to conclude that logged high neutron porosity does not represent real high porosity units with pores filled with free water. Instead, materials of relatively high thermal conductivity compared to normal basaltic material must be present in significant amounts.

The local temperature gradient variations are thus inferred to originate from variations in thermal conductivity. The latter variation is ascribed to secondary mineralisation and mineral alterations. This may produce both high conductivity minerals such as calcite, chlorite, quartz, epidote and haematite and low conductivity hydrous minerals such as clay and zeolite minerals.

Such inferred local variations in rock thermal properties are only partly reflected in our thermal conductivity measurements on core materials from the Lopra-1/1A borehole and samples from surface outcrops in the Lopra-1/1A area. These results, mostly on basalts and some on lapilli-tuff and tuff, show homogeneous conductivity with only small variations and mean values at about 1.8 (basalt) and $1.9 \mathrm{~W} / \mathrm{m}{ }^{\circ} \mathrm{C}$ (lapilli-tuff/tuff). Our measured lapilli-tuffs and tuffs generally show matrix (grain) conductivity about $20 \%$ higher than the basalts. The elevated conductivity of the former rocks may be explained by the abundance of secondary minerals with higher bulk conductivity than basalt. The increased conductivity in the originally porous part of flow units may be explained in a similar way by secondary mineralisation, as mentioned above. In some distinctly reddish intervals, haematite seems to contribute significantly to the increase in conductivity. However, further studies are needed in order to obtain a better understanding of the correlation between rock thermal properties and mineralogical alterations.

Because of the overall homogeneous mean temperature gradient structure, it is possible to obtain some information on palaeo-surface temperatures during the last glaciation by extrapolation of the temperature-depth function below $1200-1400 \mathrm{~m}$ to the ground surface. Extrapolating the depth interval $1400-2175 \mathrm{~m}$, a surface intercept of $-6.7^{\circ} \mathrm{C}$ is obtained. This is $13-14^{\circ} \mathrm{C}$ below present-day surface temperature. Although the extrapolation must be considered preliminary and approximate by nature, it suggests a temperature increase of the order of $12-16^{\circ} \mathrm{C}$ at the termination of the last glacial period.

From well-defined temperature gradients and information on mean characteristic thermal conductivity of the drilled basaltic sequences, we estimate a conductive heat flow at the Lopra-1/1A drill site of about $60 \pm 5 \mathrm{~mW} / \mathrm{m}^{2}$. This is about $15 \mathrm{~mW} / \mathrm{m}^{2}$ higher than the previous estimate from the original borehole. The revised estimate is due mainly to new, higher thermal conductivity measurements and higher estimates of the conductivity of the porous parts of the basalt flows by taking secondary mineralisations into account. A heat flow value of about 60 $\mathrm{mW} / \mathrm{m}^{2}$ is consistent with the Faroe Islands being underlain by continental crust.

From our analysis we may conclude that the thermal regime and our reported temperatures, temperature gradients and heat-flow value from below a depth of 1200$1400 \mathrm{~m}$ represent conductive equilibrium conditions without significant disturbances from the effect of drilling, ground-water flow or palaeoclimatic surface temperature variations. Temperature structure, temperature gradients and heat flow may thus be taken as representative of a larger area around the drill site with similar basaltic lithology. With respect to heat flow, an assumption of similar lithology may not be necessary. 


\section{Acknowledgements}

Valuable comments from two referees, Andrea Förster, GFZ, Potsdam and Torben Bidstrup, GEUS, Copenhagen are gratefully acknowledged. This study has been supported by funds from the Danish Natural Science Research Council.

\section{References}

Balling, N. 1995: Heat flow and thermal structure of the lithosphere across the Baltic Shield and northern Tornquist zone. Tectonophysics 244, 13-50.

Balling, N., Kristiansen, J.I., Breiner, N., Poulsen, K.D., Rasmussen, R. \& Saxov, S. 1981: Geothermal measurements and subsurface temperature modelling in Denmark. GeoSkrifter 16, 172 pp. Århus, Denmark: University of Aarhus.

Balling, N., Kristiansen, J.I. \& Saxov, S. 1984: Geothermal measurements from the Vestmanna-1 and Lopra-1 boreholes. In: Berthelsen, O., Noe-Nygaard, A. \& Rasmussen, J. (eds): The deep drilling project 1980-1981 in the Faeroe Islands. Annales Socientatis Scientiarum Faeroensis, Supplementum IX, 137-148. Tórshavn: Føroya Fróðskaparfelag.

Beck, A.E. 1988: Methods for determining thermal conductivity and thermal diffusivity. In: Haenel, R., Rybach, L. \& Stegena, L. (eds): Handbook of terrestrial heat-flow density determinations, 87-124. Dordrecht: Kluwer Academic Publishers.

Beck, A.E. \& Balling, N. 1988: Determination of virgin rock temperatures. In: Haenel, R., Rybach, L. \& Stegena, L. (eds): Handbook of terrestrial heat-flow density determinations, 59-85. Dordrecht: Kluwer Academic Publishers.

Berthelsen, O., Noe-Nygaard, A. \& Rasmussen, J. (eds) 1984: The deep drilling project $1980-81$ in the Faeroe Islands. Annales Societas Scientiarum Færoensis, Supplementum IX, 159 pp. Tórshavn: Føroya Fróðskaparfelag.

Bott, M.H.P., Sunderland, J., Smith, P.J., Casten, U. \& Saxov, S. 1974: Evidence for continental crust beneath the Faeroe Islands. Nature 248, 202-204.

Chiozzi, P., Pasquale, V. \& Verdoya, M. 2003: Heat from radioactive elements in young volcanics by $\gamma$-ray spectrometry. Journal of Volcanology and Geothermal Research 119, 205-214.

Dahl-Jensen, D., Mosegaard, K., Gundestrup, N., Clow, G.D., Johnsen, S.J., Hansen, A.W. \& Balling, N. 1998: Past temperatures directly from the Greenland Ice Sheet. Science 282, 268271.

Gariépy, C., Ludden, J. \& Brooks, C. 1983: Isotopic and trace element constraints on the genesis of the Faeroe lava pile. Earth and Planetary Science Letters 63, 257-272.

Hald, N. \& Waagstein, R. 1983: Silicic basalts from the Faeroe Islands: evidence of crustal contamination. In: Bott, M.H.P. et al. (eds): Structure and development of the Greenland-Scotland Ridge, 343-349. New York: Plenum Press.

Hald, N. \& Waagstein, R. 1984: Lithology and chemistry of a 2 $\mathrm{km}$ sequence of lower Tertiary tholeiitic lava drilled on Suðuroy, Faeroe Islands (Lopra-1). In: Berthelsen, O., Noe-Nygaard, A. \& Rasmussen, J. (eds): The deep drilling project 1980-81 in the Faeroe Islands. Annales Societas Scientiarum Færoensis, Supplementum IX, 15-38. Tórshavn: Føroya Fróðskaparfelag.

Holm, P.M., Hald, N. \& Waagstein, R. 2001: Geochemical and $\mathrm{Pb}-\mathrm{Sr}-\mathrm{Nd}$ isotopic evidence for separate hot depleted and Iceland plume mantle sources for the Palaeogene basalts of the Faroe Islands. Chemical Geology 178, 95-125.

Horai, K. 1971: Thermal conductivity of rock-forming minerals. Journal of Geophysical Research 76, 1278-1308.

Horai, K. 1991: Thermal conductivity of Hawaiian basalt: a new interpretation of Robertson and Peck's data. Journal of Geophysical Research 96, 4125-4132.

Huang, S., Pollack, H.N. \& Shen, P.-Y. 2000: Temperature trends over the last five centuries reconstructed from borehole temperatures. Nature 403, 756-758.

Iliffe, J.E., Robertson, A.G., Ward, G.H.F., Wynn, C., Pead, S.D.M. \& Cameron, N. 1999: The importance of fluid pressures and migration to the hydrocarbon prospectivity of the Faeroe-Shetland White Zone. In: Fleet, A.J. \& Boldy, S.A.R. (eds): Petroleum geology of Northwest Europe: Proceedings of the 5th conference, 601-611. London: Geological Society.

Jørgensen, O. 1984: Zeolite zones in the basaltic lavas of the Faeroe Islands. In: Berthelsen, O., Noe-Nygaard, A. \& Rasmussen, J. (eds): The deep drilling project 1980-81 in the Faeroe Islands. Annales Societas Scientiarum Færoensis, Supplementum IX, 7191. Tórshavn: Føroya Fróðskaparfelag.

Jørgensen, O. 2006: The regional distribution of zeolites in the basalts of the Faroe Islands and the significance of zeolites as palaeotemperature indicators. Geological Survey of Denmark and Greenland Bulletin 9, 123-156 (this volume).

Kappelmeyer, O. \& Haenel, R. 1974: Geothermics with special reference to application. Geoexploration Monographs. Berlin: Gebrüder Borntraeger.

Kristiansen, J.I. 1991: NEPR: A FORTRAN-77 program for determining thermal conductivity and diffusivity by needle-probe inversion. Computers \& Geosciences 17, 351-390.

Kukkonen, I.T. \& Joeleht, A. 2003: Weichselian temperatures from geothermal heat flow data. Journal of Geophysical Research 108, http://dx.doi.org/10.1029/2001JB001579.

Larsen, L.M., Waagstein, R., Pedersen, A.K. \& Storey, M. 1999: Trans-Atlantic correlation of the Palaeogene volcanic successions in the Faeroe Islands and East Greenland. Journal of the Geological Society (London) 156, 1081-1095.

Oxburgh, E.R. \& Agrell, S.O. 1982: Thermal conductivity and temperature structure of the Reydarfjordur borehole. Journal of Geophysical Research 87, 6423-6428.

Rasmussen, J. \& Noe-Nygaard, A. 1970: Geology of the Faeroe Islands. Danmarks Geologiske Undersøgelse 1. Række 25, 142 pp.

Richardson, K., Smallwood, J.R., White, R.S., Snyder, D.B. \& Maguire, P.K.H. 1998: Crustal structure beneath the Faroe Islands and the Faroe-Iceland Ridge. Tectonophysics 300, 159 180 . 
Robertson, E. \& Peck, D. 1974: Thermal conductivity of vesicular basalt from Hawaii. Journal of Geophysical Research 79, 48754888.

Roy, S. \& Rao, R.U.M. 1999: Geothermal investigations in the 1993 Latur earthquake area, Deccan Volcanic Province, India. Tectonophysics 306, 237-252.

Skogseid, J., Planke, S., Faleide, J.I., Pedersen, T., Eldholm, O. \& Neverdal, F. 2000: NE Atlantic continental rifting and volcanic margin formation. In: Nøttvedt, A. et al. (eds): Dynamics of the Norwegian Margin. Geological Society Special Publication (London) 167, 295-326.
Sundvor, E., Eldholm, O., Gladczenko, T.P. \& Planke, S. 2000: Norwegian-Greenland Sea thermal field. In: Nøttvedt, A. et al. (eds): Dynamics of the Norwegian margin. Geological Society Special Publication (London) 167, 397-410.

Verdoya, M., Pasquale, V., Chiozzi, P. \& Kukkonen, I.T. 1998: Radiogenic heat production in the Variscan crust: new determinations and distribution models in Corsica (northwest Mediterranean). Tectonophysics 291, 63-75.

Waagstein, R. 1988: Structure, composition and age of the Faeroe basalt plateau. In: Morton, A.C. \& Parson, L.M. (eds): Early Tertiary volcanism and the opening of the NE Atlantic. Geological Society Special Publication (London) 39, 225-238.

Manuscipt received 4 May 2005; revision accepted 9 September 2005. 